\title{
Urea as a Nitrogen Fertilizer for Great Plains Grasslands
}

\section{J. F. POWER}

Highlight: Economics and pollution standards indicate that urea may soon be the prime nitrogen fertilizer source in the Great Plains. Available literature was reviewed on the use of urea as a fertilizer for grasslands, particularly in semiarid regions. Results from only a few such experiments were found. However, these results agree with those from more humid or subtropical regions in that urea was as effective as ammonium nitrate at low, but not at high, rates of application. Maximum production attainable with urea is probably less than that attainable with ammonium nitrate.

Several developments within recent years indicate that urea will become the primary nitrogen fertilizer source for semiarid grasslands in the near future. Among these developments are: (a) the need for $\mathrm{N}$ fertilizers, particularly on cool season grasses in the Great Plains, is rapidly becoming more apparent in order to meet livestock demands; (b) lack of suitable application methods essentially prohibits using anhydrous ammonia on these grasslands; and (c) nitratecontaining sources, especially ammonium nitrate, may soon become prohibitive in price because of technological difficulties in controlling the emission of nitrous oxides during manufacture. Thus, only ammonium sulfate and urea remain of the conventional fertilizer $\mathrm{N}$ sources, and the price of $\mathrm{N}$ as ammonium sulfate is frequently $40 \%$ greater than that of urea (Huston, 1971). Consequently, urea may become the predominant fertilizer $\mathrm{N}$ source for the Great Plains in the foreseeable future.

Unfortunately, available publications provide the fertilizer industry and user with only limited information on the effectiveness of urea as an $\mathrm{N}$ source for

The author is research leader, U.S. Department of Agriculture, Northern Great Plains Research Center, Mandan, North Dakota.

The research is a contribution from North Central Region, Agr. Res. Serv., U.S. Dep. Agr.

Manuscript received April 25, 1973: dryland grasses. It is commonly accepted that, as urea is hydrolyzed to ammonia and carbon dioxide, significant quantities of the ammonia produced may escape to the atmosphere. Conditions that are generally conducive to ammonia volatilization include neutral or alkaline soil $\mathrm{pH}$, moderately restricted water supply, warm temperature, and presence of organic mulches. Several or all of these conditions apparently may be encountered in semiarid grasslands. Consequently, a very real question exists concerning the efficiency of urea as a fertilizer $\mathrm{N}$ source for semiarid grasslands.

This paper is a review of present information on the use of urea on semiarid grasslands. Although all pertinent references may not be included, the purpose of this paper is to point out to the reader the nature and extent of factual information available on the subject. Urea has been used as a fertilizer $\mathrm{N}$ source for semiarid grasslands in only a limited number of controlled field experiments. However, a number of laboratory and field experiments using urea with other crops or in other climates have been reported. Results of several pertinent experiments are reviewed in this paper.

Power and Alessi (1970) studied the effects of 90 and $180 \mathrm{~kg} \mathrm{~N} / \mathrm{ha}$ as ammonium nitrate, ammonium sulfate, calcium nitrate, or urea upon crested wheatgrass
(Agropyron desertorum (Fisch.) Schult.) production for 5 years. Nitrogen fertilizers were applied with or without surface broadcast $\mathrm{P}$ fertilizer. Dry weights for only the urea and ammonium nitrate treatments are shown in Table 1-yields for other $\mathrm{N}$ sources were generally similar to those obtained with ammonium nitrate. $\mathbf{P}$ fertilization increased dry matter production by $22 \%$ (10 to $50 \%$ range), regardless of $\mathrm{N}$ rate or source. At the 90 $\mathrm{kg} \mathrm{N} /$ ha rate, $\mathrm{N}$ source had no significant effect upon yields. However, urea applied at $180 \mathrm{~kg} \mathrm{~N} / \mathrm{ha}$ yielded no more than at the $90 \mathrm{~kg} / \mathrm{ha}$ rate when no $\mathrm{P}$ was added. With $P$ fertilization, there was also no response to the higher urea rate for the first 3 years of the study, but responses were evident the last 2 years. Inorganic $\mathrm{N}$ did not build up in soils receiving $90 \mathrm{~kg}$ $\mathrm{N} /$ ha annually, but frequently over 150 $\mathrm{kg}$ inorganic $\mathrm{N} / \mathrm{ha}$ accumulated in the upper $90 \mathrm{~cm}$ of soil after 5 years of fertilization at $180 \mathrm{~kg} \mathrm{~N} / \mathrm{ha}$ annually. A very noticeable exception was the treatment receiving $180 \mathrm{~kg} \mathrm{~N}$ as urea plus $P$ fertilization, where no accumulation of inorganic was found. This difference was verified by unpublished data from this experiment on residual effects from these treatments where it was found that residual responses were much greater from ammonium nitrate than from urea. After 5 years of fertilization at $180 \mathrm{~kg} \mathrm{~N} / \mathrm{ha}$ annually soil $\mathrm{pH}$ in the surface $15 \mathrm{~cm}$ decreased from 6.2 to 5.5 with ammonium nitrate and to 5.8 with urea.

In another experiment by Power et al. (1972) urea, ammonium nitrate, ammonium sulfate, and calcium nitrate were applied to both corn (Zea mays L.) and smooth brome (Bromus inermis L.) at rates of 55 and $110 \mathrm{~kg} \mathrm{~N} / \mathrm{ha}$ (fine sandy 
loam, surface $\mathrm{pH} 6.5$ ). At the $55 \mathrm{~kg} \mathrm{~N} / \mathrm{ha}$ rate, dry matter production by corn following urea fertilization was approximately equal to that following ammonium nitrate fertilization (Fig. 1). With $110 \mathrm{~kg} \mathrm{~N} / \mathrm{ha}$ however, only $73 \%$ as much dry matter was produced from urea as from ammonium nitrate. Average dry matter production by smooth brome receiving $110 \mathrm{~kg} \mathrm{~N} / \mathrm{ha}$ as urea was not significantly greater than that receiving $55 \mathrm{~kg}$ urea N/ha. Soil pH did not change appreciably as a result of fertilization with either of these $\mathrm{N}$ sources.

Fertilization was discontinued in the above experiment, and both the areas formerly in corn and in bromegrass were uniformly cropped to barley without additional $\mathrm{N}$ application, until residual growth responses were no longer significant. The fate of the fertilizer $\mathrm{N}$ applied was then determined (Power et al., 1973). For urea, $47 \%$ of the fertilizer $\mathrm{N}$ applied at $110 \mathrm{~kg} \mathrm{~N} / \mathrm{ha}$ could be accounted for by $\mathrm{N}$ uptake in tops plus inorganic $\mathrm{N}$ remaining in the root zone of the soil. Movement below the root zone was generally insignificant for smooth brome. $\mathrm{N}$ recovery averaged $82 \%$ for the other $\mathrm{N}$ sources. $\mathrm{N}$ recoveries for the corn area were 86 and $79 \%$ for urea and other $\mathrm{N}$ sources, respectively, when applied at the high $\mathrm{N}$ rate. The experiment was continued until growth responses resulting from residual effects of previous treatments were no longer statistically significant, indicating that little or no fertilizer $\mathrm{N}$ remained in plant roots, residues, or in available organic or inorganic forms. Thus, a large part of the fertilizer $\mathrm{N}$ was probably lost from the soil in gaseous form, especially by ammonia volatilization. Since all $\mathrm{N}$ fertilizers for corn were drilled about $6 \mathrm{~cm}$ deep but were surface broadcast on smooth brome, it appears that volatilization of ammonia from urea surface broadcast on a coarse-textured neutral grassland soil may become significant.

McGinnies (1968) recently published results from an experiment in which urea was applied to crested wheatgrass in eastern Colorado, but unfortunately no other $\mathrm{N}$ sources were used for comparison. Sneva (1973) found little difference between urea and ammonium nitrate when applied at $22 \mathrm{~kg} \mathrm{~N} / \mathrm{ha}$ to several dryland grasses in Oregon. Dry matter production resulting from $\mathrm{N}$ fertilization increased about $20 \%$ over a 3 year period. A review of literature for the past decade revealed no further information from field experiments involving urea fertiliza-
Table 1. Dry weight $(\mathrm{kg} / \mathrm{ha})$ of crested wheatgrass fertilized with ammonium nitrate and urea (kg N/ha), Mandan, N. Dak.

\begin{tabular}{|c|c|c|c|c|c|c|c|}
\hline \multirow[b]{2}{*}{ Year } & \multirow[b]{2}{*}{$\mathrm{N}$ fertilizer } & \multicolumn{3}{|c|}{ Without P } & \multicolumn{3}{|c|}{ With P } \\
\hline & & $0-\mathrm{N}$ & $90-\mathrm{N}$ & $180-\mathrm{N}$ & $0-\mathrm{N}$ & $90-\mathrm{N}$ & $180-\mathrm{N}$ \\
\hline 1962 & $\begin{array}{l}\mathrm{NH}_{4} \mathrm{NO}_{3} \\
\text { Urea }\end{array}$ & $\begin{array}{c}2,050 \\
- \\
-\end{array}$ & $\begin{array}{c}\overline{-} \\
4,560 \\
4,650\end{array}$ & $\begin{array}{l}- \\
5,850 \\
4,850\end{array}$ & $\begin{array}{c}2,620 \\
- \\
-\end{array}$ & $\begin{array}{c}- \\
5,140 \\
4,950\end{array}$ & $\begin{array}{c}\overline{-} \\
6,450 \\
5,240\end{array}$ \\
\hline 1963 & $\begin{array}{l}\stackrel{-}{\mathrm{NH}_{4} \mathrm{NO}_{3}} \\
\text { Urea }\end{array}$ & $\begin{array}{c}1,130 \\
- \\
-\end{array}$ & $\begin{array}{c}- \\
2,730 \\
3,330\end{array}$ & $\begin{array}{c}- \\
3, \overline{140} \\
2,980\end{array}$ & $\begin{array}{c}1,570 \\
- \\
-\end{array}$ & $\begin{array}{c}- \\
3,700 \\
3,610\end{array}$ & $\begin{array}{c}- \\
3,850 \\
3,600\end{array}$ \\
\hline 1964 & $\begin{array}{l}\mathrm{NH}_{4}-\mathrm{NO}_{3} \\
\text { Urea }\end{array}$ & $\begin{array}{c}1,010 \\
- \\
-\end{array}$ & $\begin{array}{c}-\overline{2} \\
2,420 \\
2,460\end{array}$ & $\begin{array}{c}- \\
2,590 \\
2,290\end{array}$ & $\begin{array}{c}1,120 \\
- \\
-\end{array}$ & $\begin{array}{l}\overrightarrow{3}, 120 \\
3,180\end{array}$ & $\begin{array}{c}- \\
3,120 \\
3,300\end{array}$ \\
\hline 1965 & $\begin{array}{l}\mathrm{NH}_{4}^{-} \mathrm{NO}_{3} \\
\text { Urea }\end{array}$ & $\begin{array}{c}1,780 \\
- \\
-\end{array}$ & $\begin{array}{l}-\overline{8} \\
5,880 \\
4,800\end{array}$ & 5,240 & $\begin{array}{c}2,220 \\
- \\
-\end{array}$ & $\begin{array}{c}-\overline{2} \\
6,260 \\
5,760\end{array}$ & $\begin{array}{l}\overline{-} \\
6,290 \\
6,860\end{array}$ \\
\hline 1966 & $\begin{array}{l}\mathrm{NH}_{4} \mathrm{NO}_{3} \\
\text { Urea }\end{array}$ & $\begin{array}{l}670 \\
- \\
-\end{array}$ & $\begin{array}{c}\overline{-} \\
1,820 \\
2,040\end{array}$ & $\begin{array}{r}-\overline{7} \\
1,740\end{array}$ & $\begin{array}{c}1,020 \\
- \\
-\end{array}$ & $\begin{array}{c}- \\
2,780 \\
2,280\end{array}$ & $\begin{array}{c}\overline{3}, \\
2,690\end{array}$ \\
\hline Avg & $\begin{array}{l}\mathrm{NH}_{4} \mathrm{NO}_{3} \\
\text { Urea }\end{array}$ & $\begin{array}{c}1,330 \\
- \\
-\end{array}$ & $\begin{array}{c}- \\
3,360 \\
3,460\end{array}$ & $\begin{array}{c}- \\
3,860 \\
3,410\end{array}$ & $\begin{array}{c}1,710 \\
- \\
-\end{array}$ & $\begin{array}{c}- \\
4,200 \\
3,940\end{array}$ & $\begin{array}{l}\overline{\overline{4}} \\
4,330\end{array}$ \\
\hline
\end{tabular}

tion of semiarid grasslands in North America.

Limited investigations in the Soviet Union have resulted in variable results. Generally, little difference between fertilizer sources was observed when they were applied to several grasses on various types of chernozemic and semiarid soils (Kondrst'ev and Podkolzina, 1966). Lichev (1966) reported similar results on chernozemic soils in Bulgaria. Moraczewaski (1970) found ammonium nitrate produced $6.4 \%$ more grass than urea produced on Polish chernozems at $\mathrm{N}$ rates up to $300 \mathrm{~kg} / \mathrm{ha} . \mathrm{N}$ rate was not specified in the other eastern European studies. In Spain (Suarez and Ascension, 1965), urea applied to grassland was equal to or better than ammonium nitrate, but again $\mathrm{N}$ rate was not specified. In Australia, Henzell (1971) found urea to be less effective at rates up to $448 \mathrm{~kg} \mathrm{~N} / \mathrm{ha}$, and found fertilizer $\mathrm{N}$ losses from urea to be as much as $43 \%$. Simpson (1968) reported similar losses from urea applied to ryegrass in the same region.

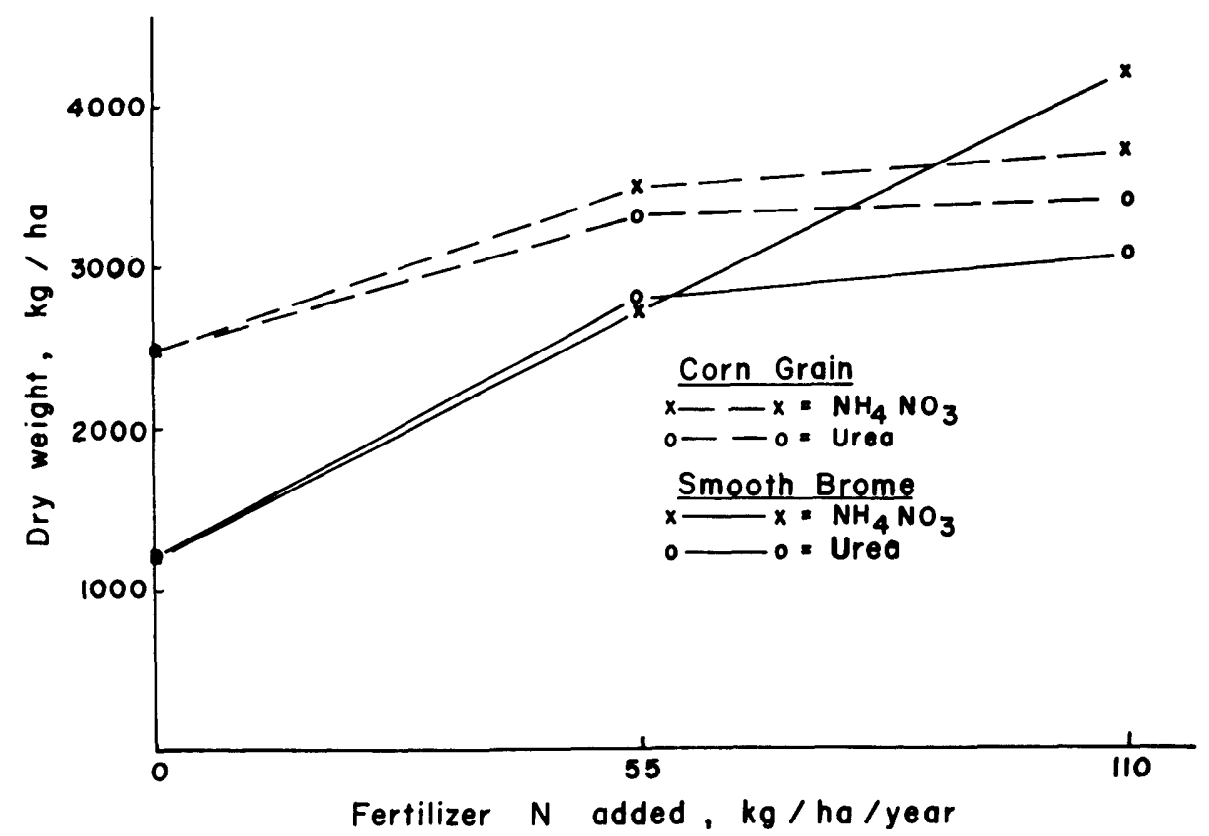

Fig. 1. Effect of ammonium nitrate and urea on dry matter production of smooth brome and corn. 
Urea has been used more frequently as a fertilizer $\mathrm{N}$ source for grasslands in the fringe areas of the Great Plains where precipitation is often greater or evapotranspiration is less. Seamands (1971) found little difference between ureaforms, ammonium nitrate, and liquid urea applied at $112 \mathrm{~kg} / \mathrm{ha}$ to mountain meadows in Wyoming. Cairns (1968) measured $55 \%$ recovery of ammonium nitrate, compared with $45 \%$ for urea, applied at $112 \mathrm{~kg} / \mathrm{ha}$ to smooth brome on solonetzic soils with high water table in Alberta. Urea was as effective as ammonium nitrate when applied to coastal bermudagrass (Cynodon dactylon L.) in Oklahoma (Hill and Tucker, 1968) at 112 $\mathrm{kg} \mathrm{N} / \mathrm{ha}$ but was inferior at $224 \mathrm{~kg} \mathrm{~N} / \mathrm{ha}$.

Urea used on grasslands in temperate humid regions and in subtropical and tropical regions has been investigated in a number of studies. Urea was as effective as ammonium nitrate (Korenkov and Filimonov, 1968; Vlasova, 1968) in only a few eastern European countries, but in these cases the $\mathrm{N}$ rate was not specified. In Western Europe (Devine and Holmes, 1963 and 1965; Furunes, 1966; Johansson and Jonson, 1964: and Mundy, 1966), eastern United States (Mays and Terman, 1969), Alaska (Laughlin, 1963), and several tropical locations (Vicente-Chandler and Figarella, 1962; Volk, 1966) urea applied at moderate-to-high rates produced less dry matter than did ammonium nitrate.

Volk (1966) illustrated that hydrolysis of urea did not occur in a dry soil, and that the process was restricted in a soil temporarily wetted. However, soil surfaces continually wetted from a water table resulted in complete hydrolysis of urea in 7 days, $65 \%$ of which was then lost, presumably by ammonia volatilization. Kresge and Satchell (1960) showed that heavy watering restricted ammonia losses. Consequently, soil water contents in the range required for plant growth appear to be conducive to ammonia volatilization.

Simpson (1968) found that gaseous losses could be reduced to almost half by removing a centimeter or two of the grass sod surface, the soil zone in which urease activity was particularly high. Likewise, Jackson and Burton (1962) reported that gaseous losses from urea applied to bermudagrass were reduced if the stubble was burned or if the soil was plowed shallow prior to fertilizer application. These and other results support the theory that gaseous losses from urea are enhanced by organic mulch present on

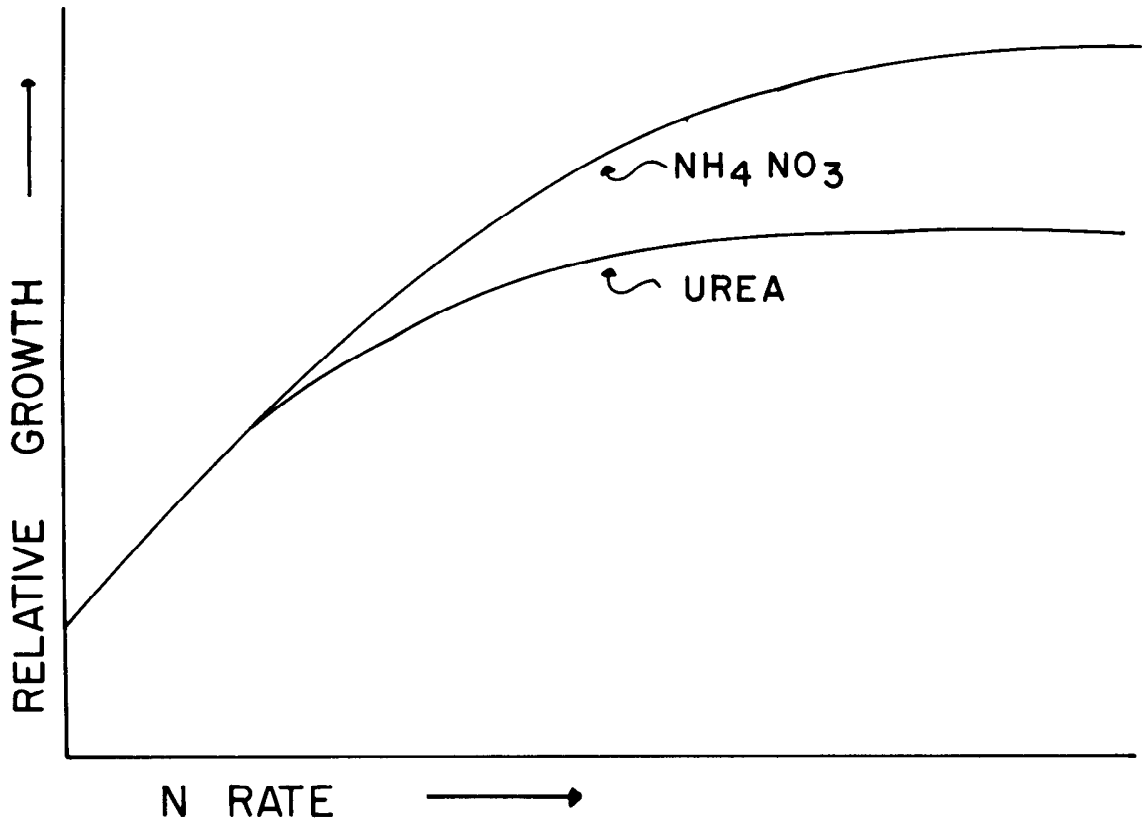

Fig. 2. Diagram showing the relation between rate of fertilization with ammonium nitrate and urea to dry matter production from grassland soils.

the soil surface.

A review of literature therefore suggests that low to moderate rates of urea are often equally as effective as ammonium nitrate for grass production. However, results of most experiments using higher $\mathrm{N}$ rates on numerous kinds of soils in many climates indicate that urea is generally 5 to $40 \%$ less effective than ammonium nitrate. These relationships are expressed for low and moderate rates in Fig. 1 , and diagrammatically for all $\mathrm{N}$ rates in Fig. 2. At low rates of $\mathrm{N}$ fertilization, urea produced essentially the same amount of grass forage as ammonium nitrate did. However, at intermediate rates, the curves began to diverge and the urea curve flattened out while the ammonium nitrate curve reached a maximum at a much higher $\mathrm{N}$ rate. Yields obtained with urea may never equal maximum yields obtainable from ammonium nitrate (Fig. 2). However, in none of the experiments cited did fertilizer rates go high enough to definitely establish this relationship. In the publications of Power et al. (1970, 1972), Henzell (1971), and Devine and Holmes (1963), data show that the response of urea compared with that of ammonium nitrate or other $\mathrm{N}$ sources decreased as rate of $\mathrm{N}$ fertilization increased for all rates studied. This suggests continued divergence of the response curves as $\mathrm{N}$ rate increases, as indicated by Fig. 2.

From the publications reviewed in this paper, urea at higher rates appears less efficient than ammonium nitrate, especially when applied to moderately moist soils that are near neutral or alkaline and are coarse in texture. Organic residues present on the soil surface may further reduce the efficiency of urea. All these conditions are frequently encountered in semiarid grasslands. Consequently, although actual field data are very limited, the data presented in the tables and figures here are somewhat typical of what might be expected in actual practice.

If further research proves these conclusions correct, the fact that urea is less efficient as an $\mathrm{N}$ source for grass production may not be as important as the fact that maximum yields obtainable with urea may be less than with ammonium nitrate. Much more research is needed to better answer these and related questions and to better establish the place of urea as an $\mathrm{N}$ source for semiarid grasslands.

\section{Literature Cited}

Cairns, R. R. 1968. Various forms of nitrogen fertilizer for bromegrass on solonetz soil. Can. J. Soil Sci. 48:297-300.

Devine, J. R., and M. R. J. Holmes. 1963. Field experiments comparing ammonium nitrate, ammonium sulfate, and urea applied repetitively to grassland. J. Agr. Sci. 60:297-304.

Devine, J. R., and M. R. J. Holmes. 1963. Field experiments on the value of urea as a fertilizer for barley, sugarbeets, potatoes, winter wheat, and grassland in Great Britain. J. Agr. Sci. 61:391-396.

Devine, J. R., and M. R. J. Holmes. 1965. Field experiments comparing winter and spring applications of ammonium sulfate, ammonium nitrate, calcium nitrate, and urea to 
grassland. J. Agr. Sci. 4:101-107.

Furunes, J. 1966. Comparison of urea and nitrates as nitrogen fertilizers for grassland and field crops, 1956-1963. Forsk. Fors. Landbr. 17:123-146.

Henzell, E. F. 1971. Recovery of nitrogen from four fertilizers applied to Rhoades grass in small plots. Austral. J. Exp. Agr. and Anim. Husb. 11:420-430.

Hill, W. E., and B. B. Tucker. 1968. A comparison of injected anhydrous ammonia into Bermudagrass sod compared to topdressed applications of urea and ammonium nitrate. Proc. Soil Sci. Soc. Amer. 32:257-261.

Huston, E. C. 1971. The nitrogen industry in the United States. TVA, Office of Agr. and Chem. Develop., Div. of Chem. Develop., Muscle Shoals, Ala.

Jackson, J. E., and G. W. Burton. 1962. Influence of sod treatment and nitrogen placement on the utilization of urea nitrogen by coastal Bermudagrass. Agron. J. $54: 47-49$.

Johansson, O., and L. Jonson. 1964. Results of field experiments with urea. Vaxt-nar-mytt 20(3):23-25. (Abstract in Commonwealth Bur. of Soils Bibliogr. No. 1373).

Kondrst'ev, I. G., and G. V. Podkolzina. 1966. Effect of urea in field experiments from results of the geographical series of experiments of NIUIF in 1958-1964. Agrokhimiya 2:3-15 (Abstract in Commonwealth Bur. of Soils Bibliogr. No. 1373).

Korenkov, D. A., and D. A. Filimonov. 1968. Effect of nitrogen fertilizers for top-dressing meadows. Agrokhimiya 4:3-9 (Abstract in Commonwealth Bur. of Soils Bibliogr. No. 1373).

Kresge, C. B., and D. P. Satchell. 1960. Gaseous losses of ammonia from nitrogen fertilizers applied to soils. Agron. J. 52:104-107.

Laughlin, W. M. 1963. Bromegrass response to rate and source of nitrogen applied in fall and spring in Alaska. Agron. J. 55:60-62.

Lichev, S. 1966. Efficiency of certain forms of nitrogen fertilizers under different soil conditions. Pochv. Agrokhim. 1:371-378 (Abstract in Commonwealth Bur. of Soils Bibliogr. No. 1373).

Mays, D. A., and G. L. Terman. 1969. Sulfurcoated urea and uncoated soluble nitrogen fertilizers for fescue forage. Agron. J. 61:489-492.

McGinnies, W. J. 1968. Effects of nitrogen fertilizer on an old stand of crested wheatgrass. Agron. J. 60:560-562.

Moraczewski, R. 1970. Potentialities of urea applied to grassland. Roczniki glebozn. 21:321-328 (Abstr. in Soils and Fertilizer 35:590 (Item 4433). 1972).

Mundy, E. J. 1966. Comparison of different sources of nitrogen for grassland when applied as liquid or solid fertilizer. Exp. Husb. 14:43-50.

Power, J. F., and J. Alessi. 1970. Effects of nitrogen source and phosphorus on crested wheatgrass growth and water use. J. Range Manage. 23:175-178.

Power, J. F., J. Allesi, G. A. Reichman, and D. L. Grunes. 1972. Effect of nitrogen source on corn and bromegrass production, soil $\mathrm{pH}$, and inorganic soil nitrogen. Agron. J. $64: 341-344$.

Power, J. F., J. Allesi, G. A. Reichman, and D. L. Grunes. 1973. Recovery, residual effects, and fate of nitrogen fertilizer sources in a semiarid region. Agron. J. 65:765-768.

Seamands, W. J. 1971. Date of application source of nitrogen study. Wyo. Agr. Exp. Sta. Bull. 541.

Simpson, J. R. 1968. Comparison of the efficiencies of several nitrogen fertilizers applied to pasture in autumn and winter. Austral. J. Exp. Agr. Anim. Husb. 8:301-308.

Simpson, J. R. 1968. Losses of urea nitrogen from the surface of pasture soils. Trans. 9 th Intern. Congr. Soil Sci. 2:459-466.

Sneva, F. A. 1973. Wheatgrass response to seasonal application of two nitrogen sources. J. Range Manage. 26:137-139.

Suarez, A., and Santos E. Ascension. 1965. Comparison of urea and ammonium nitrate for grasslands. Trab. Estac. Agr. Exp. Leo'n 2:303-316 (Abstract in Commonwealth Bur. of Soils Bibliogr. No. 1373).

Vicente-Chandler, J., and J. Figarella. 1962. Effect of five nitrogen sources on yield and composition of Napier grass. J. Agr. Univ. Puerto Rico 46:102-106.

Vlasova, V. M. 1968. Effectiveness of urea in long-term experiments. Agrokhimiya 9:14-21 (Abstract in Commonwealth Bur. of Soils Bibliogr. No. 1373).

Volk, G. M. 1966. Efficiency of fertilizer urea as affected by method of application, soil moisture, and lime. Agron. J. 58:249-252.

\section{SRM Belt Buckle}

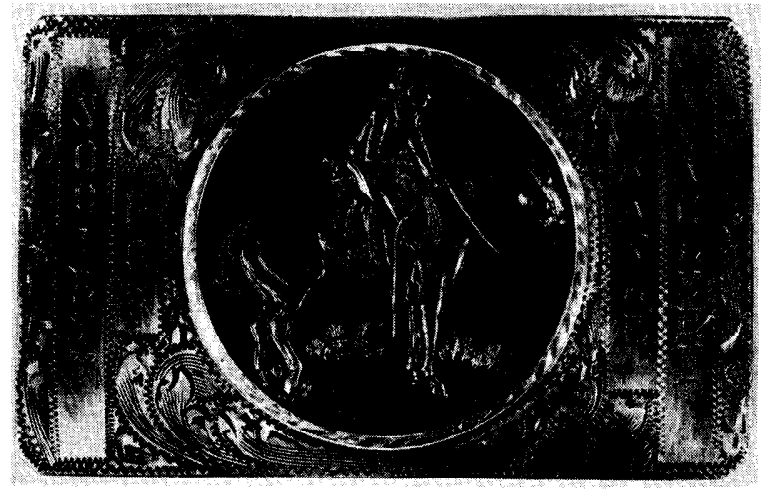

SRM "Trail Boss" belt buckles may be obtained through the Nevada Section. They are $2 \times 3 \frac{1}{2}$ inches in size and accommodate various belt widths up to $13 / 4$ inches (belt width should be specified).

The belt buckle is sterling silver with bronze Trail Boss medallion in bezel, engraved with "Society for Range Management" and scroll work @ \$45.00 postpaid.

The price is subject to change without notice. Address orders and inquiries to Richard $E$. Eckert, Jr., Renewable Resources Center, University of Nevada, 920 Valley Road, Reno, NV 89502. 